\title{
Assessing Tourism Potentials for Rebranding Nigeria
}

\author{
${ }^{1}$ Charles E. Obeta, ${ }^{2}$ Prof. J. O. Onah Fnipr, Fnimn \\ ${ }^{1}$ Department of Marketing University of Nigeria Enugu Campus \\ ${ }^{2}$ Department of Marketing University of Nigeria Enugu Campus
}

\begin{abstract}
The World Tourism organization (WTO) ranks tourism as one of the top 5 export resource for $83 \%$ of world countries and is also number one export earner for 38\% of countries worldwide. But regrettably, Nigeria's abundant tourism resources and deposits have remained grossly under exploited thereby making the country to lose much of the gains most other notable tourist destinations draw from it. Outside the common economic gains made from tourism, Nigeria is evidently ignorant of so many others. This paper holds that apart from becoming Nigeria's viable alternative to oil, tourism can indeed become the country's global brand which would ultimately alter her current negative global image. As a global brand, tourism could therefore be used to rebrand or reposition Nigeria's corporate image. A tourism development circle model is developed along this line by the paper.

Key Words: Tourism, Brands, Branding, Rebranding, Image.
\end{abstract}

\section{Introduction:}

Nigeria is indeed not only a nation of so many nationalities and cultures but, regrettably of so many images. Hence, Nigeria represents or betrays different things to different people or what public relations professionals would call multiple images. To a number of persons, the cause of the country's multiple image status is a fall out from her multi-cultural and multi-ethnic nature. To such people, the fusion or amalgamation of the northern and southern protectorates of Nigeria in 1914 was a costly accident of history that was most unnatural which if it were possible, should have been avoided. This school of thought further holds that the differences in culture, religion or belief system, values or way of life and philosophy among the segment groups of the country Nigeria smacks of differences in attitudes, behaviours and way of life which result in their obvious display of multiple images or personality or character for the country. Because there is no uniformity or commonness but differences in all ramifications among the people that make up the country Nigeria.

At another level, some hold that the country's odious or stinking image level today emanated from her colonial history having been negatively indoctrinated by the colonial masters which play out or manifests till today. Some others also hold that the country's disreputation nature is merely an out flow or display of her African mentality.

Much as these strands of opinion may sound logical, a deeper analysis would reveal something different. For instance, the issue of African mentality may not hold as records/evidences abound of so many other African countries today still with colonial and multi-cultural backgrounds yet without our type of image question especially at the international arena.

The position and the truth however is that Nigeria's image today stinks to high hell. In the international arena, Nigeria's name is not mentioned with pride and confidence and Nigerians are avoided like leprosy. Our national or corporate image to say the least, is at zero level; the level of disreputation is very high. This situation has continued to be promoted by a number of unending factors chief of which include:

i. Endemic culture and policy of corruption

ii. Poor, weak, selfish and inept leadership

iii. Poor moral value system

iv. Long-standing history of military rule

v. Decadent political, social and economic system

vi. Bastardization of the rule of law philosophy

vii. Hydra-headed social malaise

These seasoned factors are further being oiled and enhanced by the following sources in the views of Egwu, (2007:3):

i. The Niger-Delta schismogenesis and its attendant terrorism

ii. General insecurity, fraud and dishonesty

iii. Rising religious and ethnic tensions

iv. Political instability and terrorism

v. Cybernetic, drug and 419 terrorism

vi. Poverty which now stands at $80 \%$ in the country makes our image to be bad.

vii. Infrastructure decay - on land, Air, sea etc 
viii. The rentier culture and value of our political economy

ix. Falling outputs in Manufacturing, Agriculture and Petroleum sectors of the economy

x. High unemployment, making our youths very restive and workers very agitated, with incessant strikes.

The consequence of this ignoble character and status is that the country has, at different times, been dubbed an outcast or pariah nation. Such status had its attendant negative consequences and implication on the nation as many of us can still readily recall or recite. The country, for all those periods, and even now tried, and continues to recreate or reinvent itself through so many apparently fire brigade communications and public relations strategies which never reversed the negative/multiple images of the country. For instance, former Ministers of Information, Mr. Tony Momoh and Dr. Walter Ofornagoro in their bids to convince and impress their masters (mainly General Babangida) that they were alive to their duties, entertained Nigerians and the international community with their respective serialized write ups on, Letter To My Countrymen and Not In Our Character. Expectedly their image laundering efforts then could not do the magic because positive national image especially from a battered one as Nigeria had cannot be fixed either at home or abroad. It can only be earned and built to grow positively from an orchestrated, systematic, planned, organized and sustained public relations strategies. Anything to the contrary is, as Egwu (2007:22) noted, a "mere charade, sloganistic propaganda and costly gerrymandering".

Nigeria has indeed suffered and lost greatly from her poor international image and worse still, all her past efforts at reversing her negative image level have so far not provided the desired result. The question or concern then is: what should be the next line of action or best strategy at reversing the country's international image status?. What are the unexplored strategies to this serious national question?

This paper offers insight into an unexplored and untapped area which if fully and effectively harnessed would, in not too long from now, change Nigeria's current image positively. It is therefore the thesis of this paper that tourism, a grossly untapped goldmine for the country has the potentials of not only standing next to oil in terms of generating foreign exchange for the country but equally able to give Nigeria a new name within the international community. We therefore intend to explore the prospects and exploits of the tourism industry in re-branding a country like Nigeria whose global image has been in serious disrepute. The potentials of tourism in generating positive image spin-offs for the country would be analysed in this paper whose subsections have been tailored to all that.

\section{Nigeria, and Her Tourism Resources}

Nigeria, presumably the giant of Africa is richly endowed with so much in human, material and natural resources which if properly harnessed stand tall in repositioning the country. In the views of many, Nigeria can take over the place of so many countries as a popular tourist destination if her vastly scattered natural endowments are properly harnessed for social and economic benefits. Anikwe (2007:5) holds that if improved security arrangement accompanies the stubborn Nigerian Democracy (Sic) in addition to internally organized network of tourism facilities, Nigeria will surely snatch tourism destinations from a lot of third world countries. Located on the west coast of Africa between latitude $4^{\circ} \mathrm{N}$ and longitude $3^{\circ}$ and $13^{\circ} \mathrm{E}$ and covering an estimated landmass of 923, 768 square kilometers including its coastal and inland waterways and also having not less than 250 ethnic groups, Nigeria ranks among the most privileged nations of the world in terms of endowment of natural attractions. These natural endowments are scattered (in most cases untapped and unexploited) in every length and breadth of the country. The list could be endless or beyond the following:

i. the Yankari Game Reserve, in Bauchi which is a premier game reserve in Nigeria

ii. the Mambilla Plateau in the South East corner of Taraba state, mainly a very high grassland Plateau

iii. the Kainji National park in Kwara state which incorporates Borgu and Zugurma Game Reserves and the Jos wildlife Safari Park

iv. Numerous Beaches like the Lekki, the Bar, Eko, Badagry coconut Calabar beaches etc.

v. The Agbokim Water Fall in Cross River state, among others

vi. The popular Obudu Cattle Ranch which has metamorphosed to the new world class tourist centre, Tinapa

vii. Caves like the Ogbunike and Ajalli

viii. Lakes like the Agulu and Uguta

ix. Museums like the War Museum at Umuahia, the Nri Museum already taken over by the University of Ibadan as one of its research centres which attracts a number of foreign researchers/tourists yearly, the Igbo-Ukwu Museum, the National Museum at Lagos, the Esie museum in Kwara State

x. The Tinapa tourist/business centre, and a host of others

The above represent more of the class of the Eco-tourism centres in the country. Beside them exist other numerous attraction centres involving more of artworks in the area of wood and ivory carvings, brass \& bronze castings, grass and clothe weavings, pottery, painting, glass and metal works etc. For instance, there are the Ife and Benin brass and bronze castings, the grass weavings in northern parts of the country for making grass baskets, fans, tables and floor mats and also the legendary Akwete clothe weaving in Abia state, The Aso Oke 
weaving at Iseyin in Oyo state and the Ebira weaving at Okene, Kogi state. Nigeria is also blessed with popular sites of wood carvings in Benin and Awka areas and the pottery making centres in Suleja, Niger state and Okigwe, Imo state.

Nigeria's tourism resources further cover the range of the hospitality industry like hotels and other similar places of leisure and relaxation. There are world class standard 5-star hotels like the Protea, Nicon Noga, Hilton etc and other lesser class hotels which serve as prized places of visit and stay by local and international tourists. There are equally other numerous religious and cultural tourist centres in the country. Indeed, Nigeria is a tourist haven whose resources are still under explored, under-utilized and under exploited.

\section{Tourism Potentials}

The potency of tourism as a strong resource in turning the fortunes of any nation especially the developing nations is no longer in doubt. Its potentials in this direction have been widely acclaimed and highly appreciated. Hence more than ever before, tourism development and exploration are assuming major policy thrusts of most governments. For instance, Nigeria's "National Economic Empowerment Strategy (NEEDS) I \& II" strongly recommended a new focus on tourism as a means of employment generation/poverty reduction.

Accruing benefits of tourism to countries are indeed multi-faceted and multi-dimensional which underscore its growing global acceptance, recognition and application. Through in-bound and out-bound tourist movements of people, tourism touches on the economies of so many tourism destinations. In 2005 for instance, the tourism industry registered approximately 800 million international tourist arrivals world-wide so says the United Nations World Tourism Organization (UNWTO). Furthermore, the organization says that 698 million people travelled to a foreign country in 2000 spending more than US $\$ 478$ billion. It further stated that international tourism receipts combined with passenger transport currently total more than US $\$ 575$ billion-making tourism the world's number one export earner, ahead of automotive products, chemicals, petroleum and food (www.uneptie.org/pc/tourism)

Today, tourism stands tall as one of the most emerging top foreign exchange spinner for countries which WTO describes as one of its important indicators pointing out that tourism has become one of the top five export categories for as many as $83 \%$ of countries and is a main source of foreign exchange earning for at least $38 \%$ of countries. This clearly means that tourism is one of the top five export resource categories for $83 \%$ of world countries and the number one export earner for $38 \%$ of countries. This indeed places tourism at vantage position as a foreign exchange spinner for a good number of countries which explains why so many other countries yet to explore its potentials are fastly getting into it. This position is further supported by the 1999 IMF Reports which gave $\$ 504$ billion as the global trade receipts from tourism which it says makes it the highest revenue earning sector in the world. Still on this revenue generation impact, tourism is said to generate much for the US government from its National Park services. By the WTO report, $\$ 22$ billion is generated annually to the US economy from the services provided by the National Parks which in 1993 alone had a record of 273 million visits. Similarly, the World Travel And Tourism Council (WTTC) estimates that travel and tourism's direct, indirect and personal tax contribution worldwide was over $\$ 800$ billion in 1998. Which it expects to double by 2010 (i.e. next year). By National Geographic Society Reports, Dubai generates \$200 million annually from tourism and Washington Times in www.uneptie.org/pc/ tourism, tourism generated $\$ 650$ million in foreign exchange earning and received 1.2 million tourists in 1999. In Nigeria however, it is recorded that tourism accounts for a little less than $2 \%$ of Nigeria's Gross Domestic Product (GDP), which, regrettably, is not encouraging. Nevertheless, it is highly regarded as the world's biggest economic force today by Okafor (2007:5) because it circulates more money and causes more investment and social contact than any other economic factor.

Tourism contributions or impact spans through employment creation, poverty reduction, infrastructure investment and development, among so many others. According to the WTO, tourism supports some 7\% of the world workers. It can generate jobs directly through hotels, restaurants, night clubs, taxis and souvenir sales and indirectly through the supply of goods and services needed by tourism-related businesses. For example, hotel accommodation sector alone provided 11.3 million jobs worldwide in 1995 . In the Gambia, 30\% of the workforce is tourism-dependent; in Maldives, it is $83 \%, 21 \%$ in Seychelles and 34\% in Jamaica according to the WTO. The WTO further argues that "as a labour-intensive industry, tourism has the potential to create more jobs per unit of investment than any other industry and that it can be useful source of employment for women and ethnic minority groups.

With its enormous economic power and high potential for employment creation, its capacity to spread its socio-economic benefits to all levels of society and to all parts of developing and least developed, tourism can be a leading sector in the fight against poverty. This further becomes a tool for the realization of the Millennium Development Goals (MDGs) on poverty reduction.

Tourism can as well induce and stimulate local governments to provide infrastructures like better water and sewage systems, roads, electricity, telephone and public transport networks, all of which can improve the 
quality of life for both tourists and residents. And environmentally, when properly developed and managed, tourism can serve as a mechanism for protecting natural environments, preserving historical archaeological and religious monuments and, stimulating the practice of local cultures, folklore, traditions, arts and crafts, and cuisine

Indeed, tourism touches on every aspect of the economy.

\section{Concepts of Brand, Branding And Image}

The world today is overflowing with brands. Virtually everything and everybody seems to be referred to as a brand: pop stars, sportsmen, royalty, airlines, places, politicians - never mind the products that line the shelves in supermarkets or fill the shops on the high street. In this sense, anything or any label that carries some meaning or association belong to the class of brands. That is why brand today has become a very loose concept, experiencing very loose application.

For Bergh and Katz (1999:526), a brand is the name/or symbol used to identify a product or service and distinguish it from the competition. Tench and Yeomans (2006:422) refer to a brand as a label that seeks to add perceived value to a customer product by generating loyalty or preference. And for Konecnik and Gartner (2007:2), a brand can be treated as a legal instrument, logo, company, identity system, image, personality, relationship, and/or as adding value. A combination of all these perspectives is embodied in the definition provided by de Chernatony and McDanald (2001:20) which equates a successful brand to "an identifiable product, service, person or place, augmented in such way that the buyer or user perceives relevant, unique added values which match their needs most closely (and) its success results from being able to sustain these added values in the face of competition. In a rather prescriptive definition, Morgan (1999: 10) describes a brand as an entity that satisfied the following four conditions:

i. Something that has a buyer and a seller

ii. Something that has a differentiating name, symbol or trademark

iii. Something that has positive or negative associations in consumers' mind for reasons other than its literal product characteristics

iv. Something that has been created, rather than is naturally occurring.

On its own, branding simply refers to the strategic process or effort to either create, inspire, develop, generate or excite some emotional appeals or attachments in a brand with the consumers. The brand is not known or seen to be distinctive, unique or different from the competitors if it is not well branded. A brand therefore is not it if it is unbranded. Hence, branding distinguishes a product or service (the brand) from the crowd; branding communicates the uniqueness and specialty of the brand.

In the views of Onyia (2008:47), "the essence of branding is to develop emotional ties with the consumers", adding that, "it is now the brand that makes a company and no longer the product". For brands to succeed and maintain a continuous customer loyalty, their branding formular or strategy must be highly effective to the point of continually eliciting or generating reasonable emotional ties or appeals or attachments with the consumers of the brand. Brands can therefore fail or succeed; and the success or failure of brands depends on the efficacy of the branding strategy

Conceptually speaking, image on its own refers to the totality of the impressions or feelings of a people on either a product, service, place, or institution etc. Relatedly, Nadeau, et al (2008:2) hold that image represents the sum of beliefs, attitudes, and impressions that a person or group has of an object pointing out that the object may be a company, product, brand, place or person. Such impression or feeling is usually a result of some knowledge or information, experience or contact with such product, service, place or institution by the people. Image therefore exists in the mind but it is a product of some physical experience; it is a mental picture resulting from visual picture.

The relationship between the three concepts is obviously clear. A well branded brand yields a positive image of the brand or what is professionally known as brand equity. The value of the brand (which is brand image or brand equity) sustains the loyalty or patronage enjoyed by the brand from its customers which all depends on the success of the branding strategy. Brand image or brand equity is therefore a function or product of branding thus: 


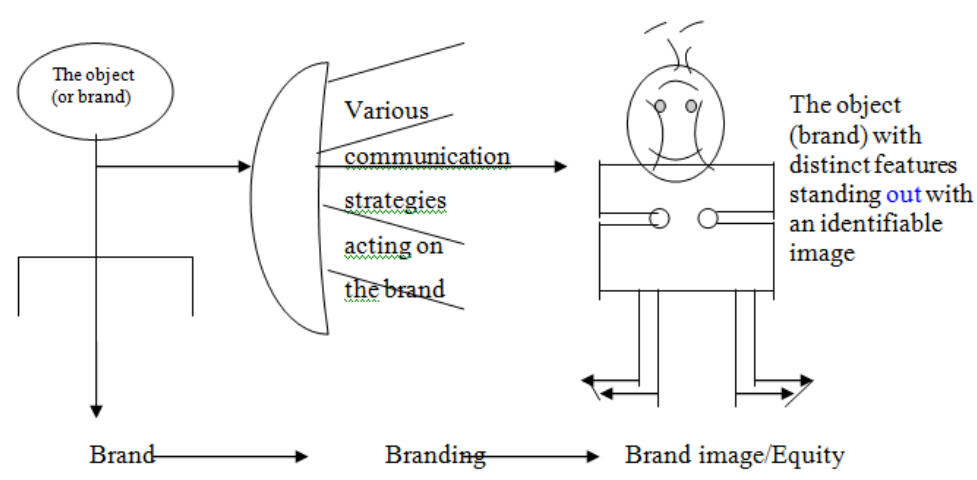

Fig. I: Brand and Branding Model

\section{Source: (the researcher)}

An effective branding tool and strategy could therefore positively raise the image of a product, service, place or institution. How tourism could serve as a tool or strategy to brand or re-brand the almighty Nigeria forms the crux of this paper which the next section zeros-in on fully.

\section{Tourism As Nigeria's Re-branding Strategy}

There is no doubt that Nigeria is richly endowed with abundant tourism resources most of which had been highlighted in the previous section. These tourism resources are scattered across the country. The appropriate question or concern here therefore is: how does tourism fit into Nigeria's re-branding tool? Can tourism be employed as a tool for re-branding Nigeria? Can it really be a strong selling point for a country whose image is at the highest negative scale? What magic wand has tourism to do this for the country?

In their study on Destination (Nepal) In A country Image Context, Nadeau, et al (2008), found a correlation between a country or destination image and tourism. They found that Nepal's attractive scenery of its natural attractions of mountains, hills and rivers as well as its built environment that showcases the cultural attractions of various temples and palaces lead to tourists' positive perceptions of the country. Tourists' overall evaluation of Nepal as a tourist destination in various assessment parameters was quite high. That resulted in their willingness to make further visits to the country and also to recommend same to other prospective tourists. If we concur with the research finding of Nadeau, and others, (2008) as stated above, then the question is: could such an image or positive impression/perception transfer be automatic with destinations? Would every tourist destination enjoy positive perception from its tourists or customers without any serious effort?. The answer definitely is No. Tourism is a product with lots of product brands which only requires effective marketing strategies to develop and generate the desired positive perceptions from the tourists. Its effective marketing strategies lie fully on branding the product brands in order to make them stand out distinctively from other destination brands. The branding of Nigeria's tourism brands would invariably be a re-branding mechanism for the country, Nigeria itself.

Agreed that tourism is an image conferral which though is not automatic, marketing the tourism destinations or brands is no less apt. What's the practical dimension of this to Nigeria? It implies effective marketing or branding of Nigeria's tourism destinations. As noted earlier, a well branded brand posts a high brand image or brand equity. Konecnik and Gartner (2007:14) in their study on Customer-Based Brand Equity For A Destination concluded that proper marketing strategies increase tourists' awareness, appeal to their image or quality perceptions or influence their loyalty dimension. They pointed out that it is necessary to employ different marketing strategies for different foreign markets. Effective marketing or branding of tourism sites/locations in Nigeria would obviously lead to their being better known to the tourists which positively affects the perception/image of such sites/locations by these tourists and finally lead to their being patronized by the tourists.

Strategic marketing campaigns should be employed to increase destination awareness, its image and quality perceptions, and consequently also the loyalty dimension. Such marketing campaigns should emphasize identity, characteristics with an aim to have an impact on tourists' destination image and quality perceptions. A tourist's awareness about a destination and positive perceptions about the image and quality dimensions can lead to visiting or to recommendation to friends and relatives. Tourism sites and locations in the country should therefore be branded or marketed at all times. This implies an all-season effective promotion of the various tourism sites/locations by highlighting and flaunting their unique and distinctive features. In brandishing these unique features, the objective should be to arouse necessary emotional ties in the tourists for these tourism sites/locations. That's the high point of the branding strategy. That our tourism industry is not yet maximizing its potentials is not the absence of the necessary endowments and features but the absence of vigorous promotions and branding strategies. 
Beside this branding or promotion, the service profile of the various tourism locations ought to be taken to the next level. The quality of services, reception, physical environment, etiquette and even after service or postvisit relations with tourists should be such that regularly reminds them of such a place and thus creates the nostalgia for repeat visits. With these, tourists would have enduring emotional attachment for the sites/locations which bring them back to the place more often.

With successful branding of the tourism industry expressed more through the orchestrated promotions that are backed up by standard laws, policies and procedures which guide compliance to the promotions by tourism locations/sites, tourists would always attract more tourists. As the popular saying goes in tourism, a satisfied tourist brings two new others when next he is coming. Because the positive impressions they receive from their receptions and services are exported home which gradually begin to alter the existing stereotypes and negative opinions of the country and ultimately, the total image of corporate Nigeria changes/improves positively. Nigeria can thus reap a lot from a more organized, planned, sustained and developed tourism industry in the country. It carries with it a lot of positive image rub off for the country.

\section{Conclusions And Recommendations:}

Tourism in Nigeria could become a strong global brand for the country when it receives the concerted attention of all the stakeholders. This is in same way that silk is a global brand for China; Mercedes and BMW for Germany; Microsoft, IBM and Ford for US; Toyota and Honda for Japan and Nokia for Finland etc (Cateora \& Graham, 2005:364-367). Positioning it as a national and global brand requires merely the strong marketing approach to it implicit in the branding and promotions that would showcase the industry's unique selling proposition (USP).

Tourism promotions in the form of awareness creations lead to perceived quality, followed by a visit and patronage and then tourism image and continued destination loyalty. This could simply be regarded or described as the tourism development cycle model (TDCM) as illustrated below which this paper strongly advocates:

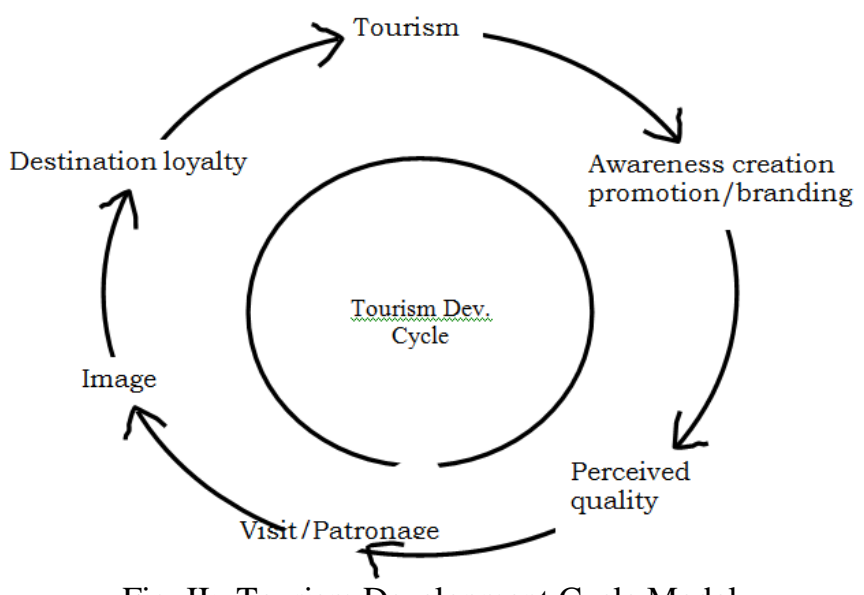

Fig. II: Tourism Development Cycle Model

\section{Source: (Modelled from Konecnik and Gartner, 2007)}

A well developed tourism industry structure for Nigeria would go a long way in repositioning the country. A well branded tourism industry would re brand the country and change its image profile especially at the international arena. This is even more apt now that the country is ambitiously posturing to be among the 20 strongest economies of the world by 2020. That desired new status demands some international trademark for Nigeria which imply some high image profile. Nigeria cannot be a serious contender to the world's G20 if she can't boast of a well developed, alluring and fascinating tourist sites/locations that would ceaselessly host local and international tourists and by extension reposition the country in the comity of nations through improved image level. The time for the application of the country's abundant tourism potentials in this direction is now. Hence we conclude with the following few recommendations.

Nigeria should urgently revisit her tourism development master plan with a view to making it more holistic by involving all the relevant stakeholders in its planning and development.

The master plan should, among others articulate standard uniform promotion policy to guide tourism service providers in their promotion and branding strategies. These service providers should regularly market and promote their services with a view to creating all necessary awareness of their uniqueness that serve as lure to tourists.

Government's international marketing/public relations programmes and strategies should incorporate tourism promotions as a way of promoting the country's international image. 
A Tourism Services Regulatory Agency to standardize the operations and services of all tourism sites/locations should be urgently established. These and more should be encapsulated in a tourism development policy blue print which should urgently be articulated.

Tourism should be fully integrated as a strong tool towards the realization and sustenance of the vision $20-2020$ project. Similarly, the re-branding of Nigeria drive by the Federal Ministry of Information and Communications cannot be attained and sustainably succeed without the support of the tourism industry. The re-branding project therefore must be built around tourism development in Nigeria.

\section{References}

[1]. Anikwe, F. I. (2007) "The Role of Community, Traditional And Religious leaders in Harnessing and Promoting tourism at the Grassroots" Being a paper Dehirered at the National Workshop on Grassroot Awareness on Tourism in Nigeria Organized by the National Institute For Hospitality \& Tourism, held at Enugu, 12-14 September.

[2]. Egwu, U. E. (2007) "Managing the Image \& Reputation of Nigeria Abroad: A critical Appraisal \& Strategic Options For Success" in Public Relations Journal, A Biannual Journal of Nigeria Institute of Public Relations, Vol 3, No. 2.

[3]. UNEP (2008) "Economic Impacts of Tourism" In www.uneptic.org/pc/tourism/sust-tourism/economic.htm,

[4]. Okafor, R. C. (2007) "Tourism: A Tool for Poverty Alleviation", Being a Paper Delivered at the National Workshop on Grassroots Awareness on Tourism in Nigeria of Enugu, 12-14 September.

[5]. Bergh, B. C. \& Katz, H (1999) Advertising Principle: Choice Challenge \& Change, Illinois: NTC Publishing Group

[6]. Tench, R and Yeomans, L. (2006) Exploring Public Relations, England: Pearson Education Ltd.

[7]. Konecnik, M and Gartner, W. C. (2007) "Customer-Based Brand Equity, for Destinations" In Tourism Management Journal Vol. 27, Issue 5.

[8]. De Chernatony, T and McDonald, M. (2001) Creating Powerful Brands in Consumer, Service and Industrial Markets, Oxford: Butterworth-Heinemann.

[9]. Morgan, A (1999). Eating the Big Fish: How Challenger Brands can Compete Against Brand Leaders. New York \& Chichester: John Wiley \& Sons.

[10]. Onyia, P. (2008) "Why Brands Fail-The 'New Coke' Example” in The Spectator, August, 15-21.

[11]. Nadeau, J, Heslop, L, O’Reilly, N Luk, P. (2008) “Destination In A Country Image Context” In Tourism Management Journal, Vol 28 , Issue 3.

[12]. Cateora, P. R. \& Graham, J. L. (2005) International Marketing $12^{\text {th }}$ Ed, Bostom: McGraw-Hill Irwin. 